$\begin{array}{lll}\text { KULTURA } & \begin{array}{l}\text { POLSKA A KADEMIANAUK } \\ \text { KOMITET SOCJOLOGII }\end{array} & \text { ISSN 0023-5172 } \\ \text { i } & \begin{array}{l}\text { INSTYTUT STUDIÓW POLITYCZNYCH } \\ \text { SPOLECLENSTHO nr } 2\end{array} & \text { PRZEMIANY WIĘZI }\end{array}$

KATARZYNA WARMIŃSKA

Uniwersytet Ekonomiczny w Krakowie

\title{
NACJONALIZM CZY POLITYKA TOŻSAMOŚCI? PRZYKŁAD KASZUBSKI*
}

Pojęcia „nacjonalizm” i „polityka tożsamości” sugerują pewien obszar tematyczny, w obrębie którego zostaną ulokowane rozważania na temat Kaszubów. Moim głównym celem będzie rozstrzygnięcie, która z tych dwóch perspektyw może być użyteczna poznawczo, i w jakim zakresie, do interpretacji dzisiejszych kaszubskich dążeń narodowych.

\section{NACJONALIZM}

Kategoria nacjonalizmu, jak twierdzą badacze tej problematyki, jest wieloznaczna, funkcjonuje zarówno w dyskursie naukowym, jak i publicznym czy politycznym. Anthony D. Smith (2007) - niewątpliwy autorytet w dziedzinie badań nad różnymi obliczami nacjonalizmu - pisał, że można wskazać dwa podstawowe parametry tego zjawiska - ujmować je jako ideologię stawiająca w centrum naród lub jako działania na jego rzecz. Można też powiedzieć — za Rogerem Brubakerem (1998, s. 13) - że nacjonalizm jest „zestawem zorientowanych na «naród» idiomów, praktyk i możliwości, które są ciągle dostępne lub «endemiczne» wobec nowoczesnego życia kulturowego i politycznego". Pojęcie narodu jest wciąż głęboko zakorzenione we współczesnych sposobach kształtowania osobistej i wspólnotowej tożsamości, stanowi ono układ odniesienia dla tworzonych wizji świata, co w swej pracy na temat nacjonalizmu podkreślał Craig Calhoun (2007, s. 131).

Adres do korespondencji: kwarminska@o2.pl

* Podstawą artykułu jest tekst ogłoszony podczas XVI Ogólnopolskiego Zjazdu Socjologicznego (wrzesień 2016) w grupie tematycznej zatytułowanej „Etniczne wyzwania naszych czasów”. 
Zmienia się jednakże oblicze tych działań, które wcześniej określane były jako nacjonalizm, co każe przemyśleć na nowo relacje między nacjonalizmem, etnicznością a samostanowieniem. Nabrały one w ostatnich dekadach nowego charakteru. Jak twierdzi Will Kymlicka (2007, s. 1), starsze formuły relacji państwo-mniejszości etniczne, oparte na polityce asymilacji i homogenizacji, są zastępowane przez multikulturowe i oparte na obywatelstwie modele państwa. Wyraża się to w większej akceptacji dla żądań formułowanych przez grupy mniejszościowe: czy to większej autonomii terytorialnej, uznania dla języka, czy prawa do samostanowienia. Można też mówić o pojawieniu się międzynarodowego czy globalnego dyskursu politycznego, który dowartościowuje różnicę kulturową w kontekście ukonstytuowania się międzynarodowych regulacji prawnych obejmujących prawa mniejszości (Kymlicka 2007, s. 2).

Badacz problematyki etnicznej Ephraim Nimni (2010, s. 22), kontynuując tę myśl, zwraca uwagę, że obecnie mamy do czynienia z rzeczywistą rewolucją w relacjach między państwami a etnokulturowymi wspólnotami. Jesteśmy bowiem świadkami swoistej ekspansji różnorodnych żądań formułowanych przez społeczności kulturowe, a zorientowanych na uzyskanie uznania ich odrębności i podmiotowości, co przybiera wiele form. Są to na przykład indygeniczne ruchy emancypacyjne czy mniejszościowe nacjonalizmy. Co ważne, w niewielkiej mierze są one zorientowane na budowanie oddzielnego państwa narodowego. Jak podkreśla Nimni, dzieje się tak dlatego, że swoje roszczenia ukierunkowują na inne cele lub po prostu nie mają szans na utworzenie własnej państwowości. Jego zdaniem, z tego względu należy zweryfikować dwa najbardziej popularne paradygmaty interpretacyjne stosowane $\mathrm{w}$ odniesieniu do kategorii nacjonalizmu: modernistyczny (Ernest Gellner, Benedict Anderson), gdzie podkreśla się rolę postulatu państwowego, i etnosymboliczny (Anthony D. Smith), na mocy którego istotna jest także relacja między narodem a państwem, choć nie jest tak ważna, jak w przypadku paradygmatu pierwszego.

Odnosząc się przede wszystkim do modernistycznych modeli nacjonalizmu, Nimni zwraca uwagę, że współcześnie wśród grup etnokulturowych spada ranga separatystycznych dążeń, czemu sprzyja to, że wiele państw ma charakter wieloetniczny czy wielonarodowy, a różne wspólnoty narodowe zamieszkują w tych samych miejscach, różnie też akomodują się do zamieszkiwanego terytorium (Nimni 2010, s. 28). Dlatego nie jest dobrym punktem wyjścia do rozumienia dzisiejszych procesów narodowych sięgnięcie do argumentacji stosowanej przez zwolenników perspektywy „postnarodowej”, którzy przyjmują założenie, że obecnie naród, etniczność czy tożsamość narodowa nie mają znaczenia. Są one bowiem nadal istotne, wielowymiarowe i widoczne na scenie społecznej. Kultura zajmuje ważne miejsce w procesach budowania tożsamości jednostki właśnie w kontekście relacji społecznych, instytucji czy symboli. Jest na wiele sposobów upolityczniona i politycyzuje tożsamości. Nimni nie formułuje wyraźnie swojej propozycji „nowego paradygmatu”, wskazuje jedynie przesłanki, które należałoby brać pod uwagę. Przede wszystkim należałoby 
uwzględnić złożoną relację między państwami narodowymi a mniejszościami w warunkach powiększania się obszaru akceptacji kulturowych praw mniejszości, lokalnie czy na forum międzynarodowym, wyłaniania się różnorakich form uczestnictwa tych grup w rządzeniu, różnorakich form godzenia kultury większościowej z mniejszościową.

Należy też dodać, że nie bez znaczenia dla rozumienia dzisiejszych procesów mających w tle naród i tożsamość narodową jest dany kontekst historyczny, polityczny czy społeczny. W dużej mierze decyduje on o treści i formie dyskursu narodowego tworzonego zarówno w obrębie grup dominujących, jak i podporządkowanych. Istotne są też czynniki ponadlokalne związane $z$ globalizującą się ideą narodu i dążeniami formułowanymi w jej duchu oraz nawiązania do koncepcji prawa jednostki do własnej tożsamości jako wartości kluczowej.

Rodzi się pytanie, czy oprócz kategorii nacjonalizmu dysponujemy innymi pojęciami, które pozwalają wyjaśniać współczesne procesy związane z tworzeniem się czy komunikowaniem idei narodowej przez aktorów społecznych, zwłaszcza mniejszościowych, działających w wielonarodowych czy wieloetnicznych organizmach państwowych, lub też, co dotyczy na przykład Polski, w warunkach silnego, hegemonicznego etnicznego nacjonalizmu państwowego. Jest możliwe oczywiście poszukiwanie kolejnej odsłony nacjonalizmu i wskazywanie nowych jego formuł. Biorąc pod uwagę daleko idące zróżnicowania w sposobach definiowania nacjonalizmu, począwszy od wspomnianych koncepcji modernistycznych, przez etnosymboliczne, po konstruktywistyczne można jedynie powiedzieć, że to, co je łączy i pozwala mówić o nacjonalizmie w sposób ogólny, to kategoria narodu — podstawowa kategoria porządkująca nacjonalistyczną wizję świata.

A jeśli postawi się w centrum uwagi tożsamość, która w ostatnich dekadach wydaje się kluczem do interpretacji wielu zjawisk współczesnego świata, także o etnokulturowym charakterze, to można posłużyć się koncepcją polityki tożsamości.

\section{POLITYKA TOŻSAMOŚCI}

W ostatnich dekadach wiele napisano o istocie tego zjawiska, wielu autorów prezentowało różne stanowiska, od analitycznych, opisowych po normatywne (Calhoun 1994; Clifford 2000; Eriksen 1999, 2013; Heyes 2002). Polityka tożsamości bowiem nie tylko wydaje się pojęciem deskryptywnym, ale też jest traktowana jako zjawisko społeczne, którego charakter stanowi przedmiot krytyki, podejmowanej zwłaszcza ze stanowisk poststrukturalistycznych czy antyesencjalistycznych (Clifford 2000; Gupta 2010). Można powiedzieć, że tak jak nacjonalizm, tak i polityka tożsamości jest kontestowaną przez niektórych badaczy.

Avigail Eisenberg i Will Kymlicka (2011) wskazują dwa główne sposoby rozumienia $\mathrm{w}$ literaturze przedmiotu polityki tożsamości. Pierwsze podejście 
określają jako normatywne, jego zwolennikami są między innymi filozofowie polityki, na przykład Charles Taylor, James Tully, Kwame Anthony Appiah czy sam Will Kymlicka. Skupieni na etycznym wymiarze postulatów tożsamościowych deliberują oni nad tym, jak dążenia do bycia uznanym przez społeczne otoczenie łączą się z szeroko rozumianymi zasadami, takimi jak wolność, sprawiedliwość, demokracja, prawa człowieka, obywatelstwo. W centrum ich zainteresowania znajduje się wyjaśnienie przyczyn siły identyfikacji ludzkiej z językiem, kulturą, religią czy terytorium, która daje asumpt do budowania uprawomocnionych żądań do bycia uznanym, a które są ignorowane czy tłumione przez nowoczesne państwo narodowe. Samo społeczne uznanie tożsamości traktują jako ważny element szacunku wobec innych i kluczowy czynnik promowania sprawiedliwości i emancypacji (Eisenberg, Kymlicka 2011, s. 2).

Przy drugim podejściu, spotykanym przede wszystkim w literaturze socjologicznej i antropologicznej, koncentruje się uwagę na badaniu procesów politycznych i społecznych, na których oparta jest politycyzacja tożsamości grupowych (Eisenberg, Kymlicka 2011, s. 3). Szczególne znaczenie przypisuje się roli elit jako tych podmiotów, które przede wszystkim organizują współziomków i ich mobilizują do działania, odwołując się do tożsamości kolektywnej. Są one siłą decydującą o celach, strategii i taktyce kolektywnych aktywności. Stają się swoiście rozumianymi przedsiębiorcami decydującymi o sposobach mobilizacji tożsamości w celu jej wzmocnienia zarówno w grupie, jak i w otoczeniu społecznym. Na procesy politycyzacji tożsamości można spojrzeć nie tylko w kontekście szczerych dążeń zwykłych członków grupy do uzyskania uznania i szacunku dla ich tożsamości, gdy czują się nieuprzywilejowani i dyskryminowani, ale przede wszystkim można je postrzegać jako instrumentalne działanie egoistycznych elit, które dążą do przejęcia rządu dusz. W takim ujęciu ważne są działania liderów podejmowane $\mathrm{w}$ grupie, a polegające na takim kształtowaniu tradycji i kultury, aby odpowiadały one ich wizjom i interesom. Mamy wtedy do czynienia $z$ dyscyplinowaniem, opresją wewnątrzgrupową. $W$ relacjach $z$ otoczeniem elity mogą przy tym na przykład strategicznie przebudowywać tożsamość grupową, tak aby pasowała do oczekiwań ze strony państwa, organizacji międzynarodowych czy hegemonicznych kategoryzacji występujących czy dominujących w danym społeczeństwie, co potencjalnie czyni tożsamość bardziej „bezpieczną” w relacjach z grupą dominującą. Jednocześnie Eisenberg i Kymlicka wskazują na ryzyko kryjące się za mobilizacją polityczną etnicznych grup tożsamościowych. Wspominają kilka kwestii: umacnianie się hierarchii wewnątrzgrupowych w społecznościach mniejszościowych, ryzyko kooptacji mniejszości (na przykład ich elit do społeczności dominującej czy tożsamości mniejszościowych do dominujących, wraz z niesionymi przez nie znaczeniami), a wreszcie ryzyko esencjalizmu, który czyni z pełnych życia wspólnot mniejszościowych podmioty uwięzione $z$ statycznym, stereotypowym rozumieniu ich tożsamości.

Opisane przez Eisenberga i Kymlickę punkty sporne każą uwzględniać złożoność zjawiska określanego jako polityka tożsamości - dostrzegać jej siłę 
emancypacyjną, ale też skutki wiążące się z uczynieniem z tożsamości celu działań kolektywnych o charakterze politycznym. Parafrazując słowa Anne Phillips, autorzy ci zwracają uwagę na to, że politykę tożsamości w aspekcie normatywnym można traktować jako kulturowego wyzwoliciela, lub też jako praktykę, która stanowi kulturowy gorset (Eisenberg, Kymlicka 2011, s 7).

Przyjmuję tu perspektywę opartą na uznaniu polityki tożsamości za kategorię opisową i analityczną, która pozwala badać różnego rodzaju działania podejmowane przez podmioty kolektywne dążące do uzyskania uznania ich tożsamości ze strony szeroko rozumianego otoczenia społecznego. W centrum uwagi badacza lokują się wtedy procesy artykulacji czy afirmacji przez podmioty społeczne określonych wizji świata w odniesieniu do kontekstu identyfikacyjnego, mobilizowanie ich na arenie życia społecznego. Polityczny aspekt takiej aktywności wynika $z$ uwikłania w przestrzeń władzy, interesu, marginalizacji i nierównego traktowania. Interesujące staje się śledzenie, jak na drodze do uzyskania uznania toczy się „praca tożsamościowa” czy praca „z tożsamością”, podejmowana zwłaszcza przez osoby zaangażowane, świadomie działające na rzecz własnej grupy w polu politycznym. Dlatego ważne jest rozpoznanie gry ze znaczeniami toczącej się wewnątrz grupy, której liderzy formułują swoje wizje świata, aby następnie promować czy propagować je wśród swoich ziomków. W ten sposób spotyka się przeszłość z teraźniejszością, ale też z przyszłością, rozumianą jako realizacja danego celu, potrzeby czy interesu.

Jak wspominałam, istotne w tej sferze jest działanie emancypacyjne, uzyskanie uznania dla danej wizji tożsamości. Politycy tożsamości zmagają się wówczas z istniejącymi uwarunkowaniami kulturowym, historycznymi czy wreszcie politycznymi, które „dopowiadają” czy narzucają warianty identyfikacyjne dostępne dla danego podmiotu kolektywnego. Determinują one te modele, które powstają w grupie, ale też te stanowiące element szerszego dyskursu. Mam tu na myśli sposoby mówienia w danym świecie społecznym o narodzie, nacjonalizmie, etniczności w kontekście identyfikacyjnym, uwikłane w dyskurs codzienny, ale też historyczny, naukowy oraz polityczny. Gdy badamy sferę polityki tożsamości, powinniśmy zwrócić uwagę na teraźniejszość. Jest to ten wymiar czasowy, w którym „dzieje się ona na naszych oczach”, przybierając postać różnych działań, których rdzeniem jest określona wizja tożsamości. Działania te mają zarazem charakter symboliczny i konkretny, zorganizowany i spontaniczny, ale też są efektem istniejących tu i teraz okoliczności, dynamicznie ustanawiających kontekst działania aktorów zaangażowanych w politykę tożsamości. Nie oznacza to całkowitego odejścia od perspektywy długiego trwania, czyli dziejących się zjawisk narodowych, co jest kluczowe dla wielu badań procesów narodowotwórczych.

Istotny w tym kontekście jest głos Rogera Brubakera, który zwraca uwagę na konieczność badania tożsamości narodowej jako „zdarzenia, jako czegoś, co raczej znienacka się rozwija oraz bardziej jako przypadkowej, koniunkturalnie zmiennej i nietrwałej ramy ujmowania czy podstawy indywidualnego i zbio- 
rowego działania niż relatywnie stabilnego produktu głębokich trendów rozwojowych w ekonomii, ustroju lub kulturze" (Brubaker 1998, s. 24). To kierowałoby uwagę, jak pisze ten autor, na perspektywę określaną jako faktualna, w myśl której tożsamość narodowa mogłaby być określona, za Calhounem, jako „zmienny produkt zbiorowego działania” (Brubaker 1998, s. 25). Takie rozumienie zjawisk narodowych bliskie jest proponowanej przeze mnie perspektywie polityki tożsamości, która wraz z całym swym instrumentarium pozwala na pokazanie skutków i przejawów, parafrazując słowa Brubakera (1998, s. 25), „bycia owładniętym strukturą narodową" (co w jego ustach ma zabarwienie negatywne) lub, mówiąc bardziej neutralnie, „bycia zorientowanym na naród”. Nie wszystko, co w dyskursie tożsamościowym ma w tytule naród, jest nacjonalizmem. Należy podkreślić, że gdy mówimy o polityce tożsamości, mamy na uwadze także problemy nierówności, marginalizacji czy mniejszościowości, które napędzają działania w jej obszarze.

Pamiętając o dylematach, które stają przed badaczami procesów tożsamościowych skupionych wokół idei narodu, postanowiłam przyjrzeć się kaszubskiej idei narodowej z perspektywy koncepcji polityki tożsamości.

\section{KASZUBI — PERSPEKTYWA PIERWSZA}

Do interpretacji kaszubskich dążeń narodowych może być zastosowana kategoria „nacjonalizm”/,ruch narodowotwórczy” i jest wówczas poznawczo użyteczna, co pokazała chociażby Ewa Michna (2007), porównując Kaszubów i Rusinów. Wychodzi ona z założenia, że istoty dzisiejszych dylematów tożsamościowych wśród elit kaszubskich należy szukać w procesach narodotwórczych, które rozpoczęły się w XIX wieku. Analizując procesy emancypacyjne Kaszubów z perspektywy historycznej, zwraca uwagę na takie czynniki, jak: wewnętrzne zróżnicowanie ruchu kaszubskiego ze względu na jego charakteru (wymiar regionalny, etniczny, etniczno-narodowy) oraz ideologię (wizja związana z myślą Floriana Ceynowy z okresu Wiosny Ludów czy Młodokaszubi i Zrzeszyńcy — orientacje, które zarysowały się w początkach XX wieku). Istotne są przy tym: geograficzne położenie, które sytuowało społeczność na skrzyżowaniu wpływów dojrzałych grup narodowych — polskiej i niemieckiej, co stworzyło alternatywę identyfikacyjną; brak aspiracji, by posiadać własne państwo; peryferyjne położenie grupy; znaczenie języka jako rdzennego elementu kultury; ważna rola elit w budowie ideowego oblicza ruchu kaszubskiego (Michna 2007).

$\mathrm{Na}$ koniec Ewa Michna jeszcze raz podkreśla, że w dzisiejszych sporach o kaszubskość wyraźnie słychać echa przeszłości, która nie tylko ukształtowała sposób mówienia o tej społeczności, ale też wyznaczyła obszar uzasadnień dla jej celów i dążeń. W tak zarysowanym obrazie procesy narodowe ukazują się jako zjawisko długiego trwania, ewoluujące, dynamiczne, przy czym przeszłość determinuje teraźniejszość. Niewątpliwie taka analiza pozwala na 
uchwycenie współczesnych zjawisk tożsamościowych w szerszym kontekście trwającego przez dziesiątki lat procesu etnicznego. Rodzi się przy tym pytanie, o zapętlenia między tym, co jest pochodną przeszłości, a obecnymi dążeniami i wizjami kaszubskich liderów. Czy nadal o swej grupie mówi się językiem poprzedników, kaszubskich przodowników narodowych? Czy też, już w nowych czasach, debata wokół idei narodowej zostaje zmodyfikowana zgodnie w wyzwaniami, jakie stawia chociażby nowoczesny dyskurs tożsamościowy, zakładający poszanowanie różnicy kulturowej, prawa do uzyskania uznania, ochronę prawną mniejszości.

Nie należy zaprzeczać istnieniu ciągłości między przeszłością a teraźniejszością, choć obecnie można zaobserwować nie tylko wyłanianie się nowych podmiotów tożsamościowych, ale też repolitycyzację historycznie ukształtowanych grup tożsamościowych, które zmierzają do ponownego sformułowania warunków uczestnictwa w społeczeństwie (Eisenberg, Kymlicka 2011). Bieżące procesy identyfikacyjne można więc dostrzec zarówno w grupach dominujących, jak i podporządkowanych.

Zamierzam, jak już wspominałam, przyjąć inną optykę niż Ewa Michna. Co nie niweluje wartości przyjętej przez nią perspektywy poznawczej. Należy raczej mówić o innym rozłożeniu akcentów w analizie procesów tożsamościowych.

\section{KASZUBI — PERSPEKTYWA DRUGA}

W obrębie grupy Kaszubów, jak i wśród jej liderów, mamy dzisiaj do czynienia ze współistnieniem kilku wersji etniczności: tradycyjną, opartą na koncepcji tubylczości (tutejszości), etniczną (kaszubską), regionalno-etniczną (kaszubsko-pomorską), regionalną (pomorską), narodową (kaszubską, polską, niemiecką). Każda $z$ nich czerpie uzasadnienie przede wszystkim z postulowanej wizji kaszubskości i swoiście dookreśla status społeczności ujmowany w kategoriach właściwych dla języka, w którym orzeka się dziś o etniczności, na przykład grupy regionalnej, etnicznej, narodowej. Zdecydowana większość badaczy etnokulturowej tożsamości kaszubskiej wskazuje, iż ma ona charakter złożony, gdyż zawiera dwa elementy integralnie połączone i nie wykluczające się - polskość i kaszubskość. Więcej na ten temat można znaleźć w publikacjach znanych kaszubologów: Brunona Synaka (1998), Cezarego Obrachta-Prondzyńskiego $(2002,2007)$ czy Moniki Mazurek (2010).

Należy zaznaczyć, że interesująca mnie koncepcja narodowa wyłoniła się w opozycji do dominującego w grupie nacisku na jej właściwości etnokulturowe. Zarówno badania socjologiczne, jak i wyniki spisu powszechnego z 2011 roku pokazują, że zdecydowana większość osób definiujących się jako Kaszubi sięga po formułę podwójnej polsko-kaszubskiej tożsamości ${ }^{1}$.

\footnotetext{
${ }^{1}$ Podczas spisu pojawiło się 232547 deklaracji tożsamości kaszubskiej, w tym dla 17746 była ona wskazana jako pierwsza (w tym dla 16377 jedyna), a w przypadku 215784 osób występowała
} 
Można mówić o trwającym wśród działaczy kaszubskich sporze tożsamościowym dotyczącym statusu etnicznego grupy. Dobrą jego ilustracją jest polemika między dwiema organizacjami kaszubskimi. Są to: Zrzeszenie Kaszubsko-Pomorskie (ZKP) i Kaszëbskô Jednotã (KJ).

Według słów odchodzącego w grudniu 2016 roku prezesa ZKP, największej organizacji zrzeszającej Kaszubów, jej linia programowa powinna skupiać się na rozwoju Kaszub jako regionu i Kaszubów jako części pomorskiej, regionalnej wspólnoty. W wywiadzie dla „Dziennika Bałtyckiego” Łukasz Grzędzicki (2016) powiedział:

„Nie możemy koncentrować się na wąskich — i w istocie zamykających nas tematach ściśle etnicznych".

Natomiast na stronie KJ kaszebsko.com czytamy, że to, co różni obie organizacje, sprowadza się do stosunku do etniczności Kaszubów oraz stosunku do polityki:

„Nasza organizacja, która zrzesza osoby deklarujące narodowość kaszubską oraz nie-Kaszubów chcących działać na rzecz kaszubskiej idei narodowej, chce kreować własną, kaszubską politykę, uznając tego typu działalność za jedno z narzędzi do osiągnięcia takich celów, jak uznanie Kaszubów za mniejszość etniczną, uczynienie Kaszubów faktycznymi współgospodarzami w regionie czy budowa społeczeństwa obywatelskiego $\mathrm{w}$ ramach samorządnego województwa pomorskiego. Warto jednak zauważyć, że KJ oraz ZKP mają wiele wspólnych celów do najważniejszych należy ochrona i rozwój języka kaszubskiego".

Poniższe rozważania powstały w wyniku analizy materiałów dwóch typów. Są to dane pochodzące $z$ wywiadów pogłębionych (45), które prowadziłam w podczas badań terenowych od roku 2008, oraz treści zawartych na stronie internetowej prowadzonej przez organizację zrzeszającą osoby narodowości kaszubskiej (kaszebsko.com). Uczestnikami badań były osoby określające się jako Kaszubi/Kaszubki, choć różnie swą kaszubskość definiowały. Byli wśród nich rozmówcy deklarujący przynależność do narodu kaszubskiego, zasadnicza część z nich należy obecnie do Kaszëbsczi Jednotë. To przede wszystkim do ich wypowiedzi będę odwoływała.

Jak już zaznaczyłam, do analizy kaszubskiego przykładu warto przyłożyć formułę interpretacyjną zawartą w koncepcji polityki tożsamości. Czyniąc tak, w pewnym zakresie będę się odwoływała również do propozycji eksplanacyjnych zawartych w szeroko rozumianej koncepcji nacjonalizmu, aby uwypuklić to, co dla niej specyficzne.

Jeśli przyjąć za modernistami, że jeden z kluczowych dla nacjonalizmu postulatów mówi o konieczności posiadania przez dany naród własnego państwa,

łącznie z polską, przy czym polska była wskazywana jako pierwsza. Ponadto 108140 osób stwierdziło, że w kontaktach domowych posługuje się językiem kaszubskim. Należy dodać, że jako język ojczysty kaszubski z zadeklarowało 13799 osób (www. gus.gov.pl). 
to w wypowiedziach moich rozmówców trudno byłoby znaleźć wątek mówiący o tego typu dążeniach politycznych. Niektórzy twierdzili wprost, że Kaszubi takich roszczeń nie mają. W wywiadach wielokrotnie podkreślano różnicę między narodowością a obywatelstwem jako dwoma odmiennymi kontekstami identyfikacyjnymi. Dla Kaszubów jako narodu kulturowego - takie określenie pojawiło się $\mathrm{w}$ wypowiedziach - istotne jest poczucie wspólnoty, własna kultura, język i świadomość, a jeśli już jakaś formuła niezależności od dominującej społeczności narodowej, to pewien zakres autonomii kulturowej czy samorządności. Państwo polskie jawiło im się, z jednej strony, jako polityczna wspólnota przynależności, w której Kaszubi mają swoje miejsce jako obywatele — a więc „swoje” państwo już posiadają. $Z$ drugiej natomiast — było ono kontestowane jako opresyjne, wywierające presję asymilacyjną, co zostało uznane za zagrożenie dla zachowania kaszubskiej odrębności narodowej. W tym drugim ujęciu ma ono polski/narodowy charakter, co oznacza dominację jednej grupy nad pozostałymi, które też są częścią wspólnoty politycznej. Można więc powiedzieć, ze stosunek Kaszubów do państwa ma charakter ambiwalentny, przy czym bardzo istotne, zwłaszcza dla działaczy KJ, jest odpowiednie ułożenie relacji między Kaszubami a państwem. Na stronie internetowej czytamy:

„Kaszëbskô Jednota” jest stowarzyszeniem osób chcących aktywnie uczestniczyć w życiu narodu kaszubskiego i uznających jego prawo do odrębności oraz własnej tożsamości w ramach wieloetnicznego społeczeństwa tworzącego jeden organizm państwowy, jakim jest Rzeczpospolita Polska".

Państwo jest bardzo istotnym adresatem postulatów formułowanych w imię kaszubskiego narodu. Wyraźnie ukazuje się to mniejszościowe położenie Kaszubów jako grupy dążącej do uzyskania uznania dla własnego sposobu istnienia $\mathrm{w}$ polu etnicznym, które $\mathrm{w}$ wysokim stopniu jest definiowane przez państwo jako głównego aktora politycznego. W obrębie możliwości narzuconych, między innymi przez państwo, formułowane są postulaty w imię kaszubskiego „my”. Na stronie Kaszëbsczi Jednotë napisano: „Stowarzyszenie domaga się prawnej legalizacji narodu kaszubskiego oraz objęcia go pełną ochroną przez Rzeczpospolitą Polską”. Uzyskanie owej „legalizacji” jest jednym z podstawowych celów kaszubskich działaczy skupionych wokół idei narodowej zrzeszonych w tej organizacji.

Nacjonalizm to jednak nie tylko postulat polityczny. W centrum dyskursu nacjonalistycznego znajduje się naród, zwykle traktowany jako byt substancjalny, realny. Zgodnie z tą wizją każdy naród ma swój charakter, swoją historię, przeznaczenie, lojalność wobec niego jest najważniejsza (Smith 2007). Moi rozmówcy definiowali naród kaszubski przez odwołanie do funkcjonujących w nauce definicji: zarówno tzw. obiektywistycznych, w których wymienia się kryteria (język, terytorium, pochodzenie, tradycje, pamięć), jakie powinna spełniać grupa o charakterze narodowym, jak i subiektywistycznych, kładących nacisk na samoprzypisanie. Swobodnie sięgali do słownika dyskursu narodo- 
wego, który jak pisał Calhoun (2008), jest obecnie w obiegu społecznym łatwo dostępny dla grup formułujących swe aspiracje narodowe. Jednak zdawali sobie przy tym sprawę $z$ tego, że o narodzie można mówić na wiele sposobów. Co więcej, w ich opinii, Kaszubów jako wspólnotę daje się opisać różnorako, niekoniecznie jako naród. Można było dostrzec z jednej strony wizję Kaszubów jako narodu, z którym badani się identyfikują i używają przy tym kategorii „my”. $Z$ drugiej strony zaś pojawiało się wyobrażenie pewnego substratu, który można określić jako „kaszubskość” i który w zależności od przyjętej wobec niego postawy może przybierać różne formy, w tym formułę narodu. Na podstawie analizy materiału empirycznego daje się stwierdzić, że wśród Kaszubów wpisanie się w ideę narodową jest przede wszystkim kwestią wyboru i świadomości. Istnieje — jak czytamy chociażby na stronie Kaszëbsczi Jednotë — coś takiego, jak kaszubska opcja narodowa, ale są też inne sposoby samoopisu, zdaniem badanych $\mathrm{w}$ równym stopniu uprawnione. Jak twierdzili, jedni odnajdują siebie w projekcie narodowym, inni określają się jako Polacy-Kaszubi, jeszcze inni przyjmują definicję ustawową (społeczność posługująca się językiem regionalnym), a kolejni nie zdają sobie jeszcze sprawy, kim są.

Można więc zadać pytanie, jak naród istnieje w świadomości moich rozmówców? Czy jako byt substancjalny, co jest charakterystyczne dla myśli nacjonalistycznej, która w nawiązaniu do tak rozumianego „my” formułuje swoje postulaty. Byt substancjalny w tym sensie, że do jego opisu można używać na przykład kategorii ,jest”, „posiada”, co oznacza, że ma niezależną podmiotowość i sprawstwo, a tym samym zreifikowany charakter. Czy też jest to raczej byt przygodny, istnieje warunkowo, gdyż jest usytuowany przede wszystkim w świadomości poszczególnych Kaszubów, co jego istnienie legitymizuje. Nie można dać tu jednoznacznej odpowiedzi, gdyż w narracjach można było usłyszeć, że „Kaszubi są narodem”, kiedy indziej zaś, że istnieje coś takiego jako kaszubski substrat, z którego może wyłonić się naród, przywoływano także inne formuły tożsamościowe, różne formy kulturowego samookreślenia. Można więc powiedzieć, że istnienie narodu niekoniecznie predefiniuje tożsamość, która jest emanacją ducha wspólnoty. Naród jest opcją do wyboru — aktualizuje się w tożsamości swoich członków i to ludzie stwarzają naród kaszubski, mniej lub bardziej uświadamiając sobie, kim są, podejmując działania na rzecz narodu, choć nie jest to konieczne, lecz stanowi wynik wyboru. Na pytanie, czy Kaszubi są narodem, umieszczone w zakładce FAQ na stronie kaszebsko.com czytamy:

„Narodowość (przynależność narodowa lub etniczna) jest deklaratywną, opartą na subiektywnym odczuciu, indywidualną cechą każdego człowieka, wyrażającą jego związek emocjonalny, kulturowy lub wynikający z pochodzenia rodziców z określonym narodem lub wspólnotą etniczną. W spisie ludności z 2011 r. (z którego pochodzi powyższa definicja) po raz pierwszy umożliwiono wyrażanie złożonych tożsamości narodowo-etnicznych. My czujemy się narodem. Naszym zdaniem, wzorem Floriana Ceynowy, Młodokaszubów z Aleksandrem Majkow- 
skim na czele, Zrzeszińców, a także 17 tys. osób deklarujących narodowość kaszubską w Narodowym Spisie Powszechnym w 2011 roku — Kaszubi mają pełne prawo do nazywania siebie narodem, gdyż jest to kwestią samostanowienia i autoidentyfikacji w dzisiejszym świecie".

Powyższe słowa z jednej strony nawiązują do subiektywistycznych koncepcji narodowości jako identyfikacji z istniejącą wspólnotą. W tym sensie tożsamość jest korelatem narodu. $Z$ drugiej strony zaś naród jest korelatem tożsamości, gdyż — jak czytamy — to na mocy autoidentyfikacji narody powstają. Taka podwójna formuła definiująca relację między wymiarem identyfikacyjnym, do którego przede wszystkim odnoszą się politycy tożsamości, a koncepcją wspólnoty jest na tyle szeroka, że pozwala swobodnie budować argumentację, która w zależności od kontekstu służy różnym celom czy interesom grupy.

W odniesieniu do tak zarysowanej wizji najistotniejsza jest, jak twierdzili badani, praca nad świadomością, jej wzbudzanie, utrzymywanie, budowanie, gdyż stanowi ona gwarancję przetrwania kaszubskiego narodu. Dlaczego jest to ważne dla polityków tożsamości? Kluczową kategorią tego dyskursu jest tożsamość nasycona/nasycana treściami narodowymi. Zgodnie z typową dla polityków tożsamości logiką można powiedzieć, że ich przedsięwzięcia przede wszystkim potrzebują kategorii „my”. Budowana jest ona w odniesieniu do tożsamości poszczególnych osób, one legitymizują retorycznie taką wizję/postulat. Następnie w imię powołanego do życia tożsamościowego podmiotu kolektywnego można formułować potrzeby i dążenia i z ich perspektywy prowadzić politykę. Tym samym też uprawomocnia się i potwierdza istnienie owego „my”.

Jeśli zgodzić się z Michaelem Billigiem (2008, s. 290), iż polityka tożsamości jest filozofią pierwszej osoby liczby mnogiej, która daje asumpt do tworzenia wizji grup etnokulturowych, to tak właśnie jest w przypadku moich badanych. Metaforycznie rzecz ujmując, kaszubska idea narodowa ucieleśnia się przede wszystkim w tożsamości poszczególnych osób. To w imię takiej tożsamości formułowane są postulaty, ona jest główną siłą sprawczą w relacjach społecznych oraz ważnym zasobem. Co ciekawe, jeśli przyjmiemy, że postulaty wskazane wyżej wpisują się w pewnym zakresie w te, które były i są formułowane przez budzicieli narodowych, to $\mathrm{w}$ czym tkwiłaby różnica między nimi a politykami tożsamości. Wskazałabym tu przede wszystkim większą dozę otwartości w odniesieniu do ujawniania „kuchni tożsamościowej”. Mam na myśli swoiste „odarcie z tajemnicy” procesu budowania narodu i tożsamości. Można bowiem „na bieżąco" obserwować, chociażby śledząc internet, jak wyłaniają się współczesne idee narodowe, jak konstruowane są zarówno wizje, jak i działania zorientowane $\mathrm{w}$ ten sposób. Idea narodowa „wchodzi do obiegu”, można nad nią dyskutować czy ją kontestować, ale jest też uwspólniana przez uczestnictwo w pewnych praktykach dyskursywnych, które funkcjonują w cyfrowym obiegu. Budziciele narodowi stający się politykami tożsamości muszą „trzymać rękę na pulsie”, reagować na pojawiające się w ich grupie głosy czy argumenty, a tak- 
że na te, które słychać w szeroko rozumianym dyskursie publicznym. Stają się raczej działaczami, przedsiębiorcami, organizatorami.

Kolejnym argumentem za stosowaniem modelu interpretacyjnego odnoszącego się po polityki tożsamości jest fakt, iż moi rozmówcy pytani o dążenia czy cele wspominali raczej nie o dążeniu do szeroko definiowanej emancypacji narodowej, chociaż i takie zdania się pojawiały, lecz o konkretnych działaniach o charakterze formalnoprawnym. Ich podstawowy postulat dotyczy zmiany zapisu ustawowego i uznania Kaszubów za mniejszość etniczną. Pozornie brzmi to paradoksalnie, jeśli naród chce być wpisany w tę specyficzną formułę i w ten sposób uzyskać ze strony państwa potwierdzenie własnej podmiotowości. Jednak dla polityków tożsamości, którzy poszukują przede wszystkim możliwie korzystnego dla grupy usytuowania w istniejącym układzie, taki postulat jest sensowny, gdyż pozwala działać. W analizowanym przykładzie „budowanie narodu" przybiera formę zinstytucjonalizowaną, w postaci powołania do życia stowarzyszenia, które ma działać w imieniu i na rzecz osób narodowości kaszubskiej. Szukając jakiejś formuły organizacji wspólnych dążeń i takiej, która pomogłaby dbać o dobrostan kaszubskiego „my” (którą kiedyś, w dobie wielkich nacjonalizmów mogłoby być własne państwo), dzisiejsi kaszubscy działacze widzą siłę w stowarzyszeniu się ludzi o podobnych poglądach na kaszubską sprawę, zainteresowanych działaniem na rzecz kaszubskiej idei narodowej, świadomych własnej tożsamości. Takie „zorganizowanie się” staje się platformą, na bazie której można reprezentować kaszubskie interesy, budować formułę przedstawicielstwa, promować wśród współziomków „opcję narodową”.

Badacze polityki tożsamości zwracają uwagę na praktyki esencjalizujące względem tożsamości podejmowane przez aktywistów politycznych. Wyrażają się one w tworzeniu, $w$ imię interesów grupowych, realizowanych na arenie stosunków etnicznych, jednowymiarowych, zreifikowanych opisów grupowych charakterystyk zacierających wewnątrzgrupowe zróżnicowania. To swoiste dyscyplinowanie jest kolejną odsłoną pracy tożsamościowej, realizowanej nie tylko przez działaczy Kaszëbsczi Jednotë, ale też oponenta czyli Zrzeszenia Kaszubsko-Pomorskiego. Co ciekawe, jeśli wsłuchać się w wypowiedzi moich rozmówców, ich wizje tożsamościowych właściwości Kaszubów są w pewnym sensie rozmyte, zwłaszcza jeśli wziąć pod uwagę te twierdzenia, które mówią, że Kaszubą można być na wiele sposobów lub Kaszubą może być ten, kto za takiego się uważa i działa na rzecz grupy. W tym sensie praktyki esencjalizujące nie wydają się intensywne, choć wybór opcji narodowej oparty jest na modelu identyfikacyjnym, w którego centrum znajdujemy się „my” — Kaszubi (utożsamiający się z kaszubskim narodem), w imieniu których i na rzecz których należy działać. W tym sensie można mówić o domykaniu tożsamości w obrębie danego konceptu - narodowego czy zakładającego istnienie podwójnej tożsamości.

$\mathrm{Na}$ koniec chciałam podkreślić, że moi rozmówcy, a także działacze Kaszëbsczi Jednotë nie określają się mianem nacjonalistów kaszubskich, co jest po części zrozumiałe ze względu na usytuowanie ich społeczności w kraju, w którym 
kategoria ta ma znaczenie negatywne, zwłaszcza gdy wiąże się z dążeniami społeczności mniejszościowych. Co ciekawe, za nacjonalistów byli uznawani przez oponentów w ich własnej grupie, zwłaszcza gdy pojawił się postulat założenia Kaszubskiej Partii Narodowej, od czego wyraźnie odcięło się Zrzeszenie Kaszubsko-Pomorskie. Określenie to miało zdeprecjonować te zamiary. Dzisiejsi zwolennicy opcji narodowej mówią o sobie jako o politykach tożsamości (to określenie pojawia się wprost na stronie kaszebsko.com) i za swe cele uznają wzbudzenie, ożywienie wśród Kaszubów tożsamości narodowej czy prowadzenie polityki kulturowej. Jak powiedział jeden z rozmówców, ich celem jest doprowadzić do tego, aby nierefleksyjni stali się refleksyjni, aby ludzie zechcieli być Kaszubami w sensie narodowym. Idąc za perspektywą emiczną, powinniśmy zatem spoglądać na nich samych i ich działania właśnie w kontekście owej praktyki politycznej odnoszącej się do sfery tożsamości.

\section{PODSUMOWANIE}

W pewnej ogólnej perspektywie można zastanowić się nad sensownością zastosowania do przedstawianego tu kaszubskiego przykładu kategorii „nacjonalizmu” i „polityka tożsamości”. W pierwszym przypadku możliwa jest interpretacja $\mathrm{w}$ kontekście procesów długiego trwania, istotnego dla procesów narodowotwórczych i rozwoju nacjonalizmu, i wskazanie na silne powiązania z pewną wizją historii czy przeszłości, która odżywa w dzisiejszym kaszubskim dyskursie tożsamościowym. Odwołania do dawnych kaszubskich budzicieli pojawiają się zarówno wśród zwolenników, jak i oponentów opcji narodowej. Daje się tu dostrzec kontynuacja pewnych idei. W przypadku drugim należy wziąć pod uwagę nowe uwarunkowania, w których przyszło żyć dzisiejszym Kaszubom, co skłania do przyjęcia innej perspektywy, niż ta oparta na założeniu o kontynuacji. Te nowe uwarunkowania to zarówno istniejące tu i teraz kaszubskie tożsamościowe status quo, jak i parametry świata zewnętrznego, który nie tylko narzuca formuły samookreślenia odpowiadające istniejącym dyskursom etnokulturowym, ale też wskazuje sposoby, jak można się upodmiotowić, jak działać na rzecz postulowanej wizji „my”. Dlatego w postawach i działaniach części kaszubskich działaczy możemy obserwować całe spektrum aktywności skupionych właśnie na kategorii tożsamości, w znaczeniu kolektywnym, podlegającej unarodowieniu na mocy ich pracy nad tym właśnie zasobem. W konsekwencji wyłania się ideologia pewnej tożsamości niż ideologia pewnego narodu.

\section{BIBLIOGRAFIA}

Billig Michael, 2008, Banalny nacjonalizm, tłum. Maciej Sekerdej, Znak, Kraków.

Brubaker Rogers, 1998, Nacjonalizm inaczej. Struktura narodowa $i$ kwestie narodowe w nowej Europie, tłum. Jan Łuczyński, Wydawnictwo Naukowe PWN, Warszawa-Kraków. 
Calhoun Craig, 1994, Social Theory and the Politics of Identity, w: Craig Calhoun (red.), Social Theory and the Politics of Identity, Blackwell, Oxford.

Calhoun Craig, 2007, Nacjonalizm, Wydawnictwa Akademickie i Profesjonalne, Warszawa.

Clifford James, 2000, Taking Identity Politics Seriously: the Contradictory, Stony Ground ..., w: Paul Gilroy, Lawrence Grossberg, Angela McRobbie (red.), Without Guarantees: Essays in Honour of Stuart Hall, Verso Press, London.

Eisenberg Avigail Will Kymlicka Will, 2011, Bringing Institutions Back in How Public Institutions Asses Identity, w: Avigail Eisenberg, Will Kymlicka (red.), Identity Politics in the Public Realm. Bringing Institutions Back in, UBC Press, Vancouver-Toronto, s. 1-30.

Eriksen Thomas Hylland, 1999, Globalization and the politics of identity, „UN Chronicle. The Magazine of the United Nations", autumn, www.eriksen.net [15.05.2014].

Eriksen Thomas Hylland, 2013, Etniczność i nacjonalizm. Ujęcie antropologiczne, tłum. Barbara Gutowska-Nowak, Wydawnictwo Uniwersytetu Jagiellońskiego, Kraków.

Grzędzicki Łukasz, 2016, Otwartość nie osłabia kaszubskiej tożsamości. Rozmowa z Łukaszem Grzędzickim, ustępującym prezesem Zrzeszenia Kaszubsko-Pomorskiego, 9 grudnia (www.dziennikbałtycki.com).

Gupta Suman, 2007, Social Constructionist Identity Politics and Literary Studies, Palgrave Macmillan, Basingstoke.

Heyes Cressida, 2002, Identity Politics, „The Stanford Encyclopedia of Philosophy” (http://plato. stanford.edu/archives/fall2002/entries/identity-politics [15.05.2014]).

Kymlicka Will, 2007, Navigating the New International Politics of Diversity, Oxford University Press, Oxford.

Mazurek Monika, 2010, Jęzk, przestrzeń, pochodzenie. Analiza tożsamości kaszubskiej, Instytut Kasuzbski, Gdańsk.

Michna Ewa, 2007, Dylematy tożsamościowe grupy pogranicza. Na przykładzie analizy porównawczej ruchu karpatorusińskiego i kaszubskiego, w: Cezary Obracht-Prondzyński (red.), Kim sq kaszubi? Nowe tendencje w badaniach społecznych, Instytut Kaszubski, Gdańsk.

Nimni Ephraim, 2010, Nationalism, Ethnicity, and Self-Determination: A Paradigm Shift, w: Keith Breen, Shane O'Neill (red.), After the nation? Critical Reflections on Nationalism and Postnationalism, Palgrave Macmillan, New York.

Obracht-Prondzyński Cezary, 2002, Między dyskryminacją a regionalna podmiotowością, Instytut Kaszubski, Gdańsk.

Obracht-Prondzyński, Cezay (red.), 2007, Kim sa Kaszubi? Nowe tendencje w badaniach społecznych, Instytut Kaszubski, Gdańsk.

Smith Anthony D., 2007, Nacjonalizm: teoria, ideologia, historia, tłum. Ewa Chomicka, Wydawnictwo Sic!, Warszawa.

Synak Brunon, 1998, Kaszubska tożsamość - ciagłość i zmiana - studium socjologiczne, Wydawnictwo Uniwersytetu Gdańskiego, Gdańsk.

\title{
NATIONALISM OR IDENTITY POLITICS? THE EXAMPLE OF THE KASHUBS
}

\author{
Katarzyna Warmińska \\ (Kraków University of Economics)
}

\section{Summary}

The author focuses on the national emancipation strivings of part of the Kashubian elite in Poland. She proposes two interpretive views that could be helpful in under- 
standing the ethnic processes presently occurring in the Kashubian community. The first derives from the category of nationalism, while the second refers to the concept of identity politics. The use of each makes it possible to perceive various aspects of the Kashubian national idea, although, as the author argues, the perspective of identity politics appears to be of more research interest and was the view primarily employed in analyzing the empirical material.

\section{Key words / słowa kluczowe}

nationalism / nacjonalizm, national idea / idea narodowa, identity politics / polityka tożsamości, Kashubs / Kaszubi 